Man and Nature

MAN AND NATURE

L'homme et la nature

L'HOMME ET LA NATURE

\title{
Lavoisier, Priestley, and the Philosophes: Epistemic and Linguistic Dimensions to the Chemical Revolution
}

\section{John G. McEvoy}

Volume 8, 1989

URI : https://id.erudit.org/iderudit/1012600ar

DOI : https://doi.org/10.7202/1012600ar

Aller au sommaire du numéro

Éditeur(s)

Canadian Society for Eighteenth-Century Studies / Société canadienne d'étude du dix-huitième siècle

ISSN

0824-3298 (imprimé)

1927-8810 (numérique)

Découvrir la revue

Citer cet article

McEvoy, J. G. (1989). Lavoisier, Priestley, and the Philosophes: Epistemic and Linguistic Dimensions to the Chemical Revolution. Man and Nature / L'homme et la nature, 8, 91-98. https://doi.org/10.7202/1012600ar

Copyright (c) Canadian Society for Eighteenth-Century Studies / Sociéte canadienne d'étude du dix-huitième siècle, 1989
Ce document est protégé par la loi sur le droit d'auteur. L'utilisation des services d'Érudit (y compris la reproduction) est assujettie à sa politique d'utilisation que vous pouvez consulter en ligne.

https://apropos.erudit.org/fr/usagers/politique-dutilisation/ 


\section{Lavoisier, Priestley, and the Philosophes: Epistemic and Linguistic Dimensions to the Chemical Revolution}

The Chemical Revolution occurred towards the end of the Enlightenment. It embodied the philosophical aims and principles inherent in the innovative notion of the knowing subject that was emerging in the minds of the philosophes. The philosophers of the Enlightenment forged the modern concept of the self-defining subject. ${ }^{1}$ Medieval and earlyRenaissance thought defined the self in relation to the cosmic order, and equated reason with the eternal verities held in common by the human and the divine mind. Reason linked the cosmic order and the human subject in a relationship of reflection and systematic correspondence. The real task of knowledge on this view was the construction of metaphysical systems, based on intrinsic, a priori links between the knowing subject and the cosmic order, in which the method of proof and rigorous inference was used to spread the light of certainty over derived being and knowledge. The Enlightenment mind, in contrast and in reaction to this perspective, rejected the idea of an intrinsic link between the self and the cosmos: the knowing subject encounters the world as something other, as a set of de facto, contingent correlations. Drawing back from the world, the self-defining subject concentrates on the nature and limits of its own activity. The eighteenth century was characteristically an age of epistemology, psychology, and methodology.

Within this new framework of thought, reason was no longer identified with a sound body of knowledge; it was viewed instead as an activity characteristic of man, as a method of enquiry which guided the discovery of truths. Reason was not embedded in a metaphysical system; rather it operated through the methods of the empirical sciences. This, for the eighteenth-century mind, was the essence of Locke's rejection of innate ideas and Newton's method of analysis, which moved from phenomena to principles and not vice versa. The method of analysis understood an event by analyzing it into its elements, from which it was then reconstituted or synthesized. Science could progress independently of metaphysics, which, like all other disciplines, should subject itself to the analytical methods and results of 
the sciences. In replacing metaphysical reason, grounded in things, with scientific reason, anchored to method, the Enlightenment mind replaced the Renaissance doctrine of signatures, which posited an intrinsic link between words and things, with the view of language as a representational system of signs which are independent of the things they represent. Within this linguistic framework, the method of science and the language of science were necessarily linked to the epistemological procedure of classification.

The Chemical Revolution captured something of the characteristic unity of the philosophical mind of the Enlightenment to the extent that, despite their considerable intellectual differences, Lavoisier and Priestley shared an abiding commitment to the liberation of science from metaphysics, a strong desire to deploy the method of analysis in the understanding of nature, and a deep sense of the epistemological significance of reforming the language of science and reconstructing the nomenclature of chemistry. The fact that Lavoisier and Priestley pursued radically different scientific objectives and reached fundamentally opposed conclusions within a shared framework of regulative principles lends support to the interpretation of the Enlightenment as a coherent and self-conscious movement of epistemological and methodological reform which encompassed a wide range of opinions and doctrines about the world. ${ }^{2}$

At the core of the chemical dialectic was the polarity between Lavoisier's notion of an active, social, hierarchical knowing subject and Priestley's concept of a passive, individualistic, egalitarian epistemic self. In this manner, the Enlightenment view of the self-defining subject was shaped according to the different structural and organizational features of French and British science and society. Within this wider framework, this essay will concentrate on the epistemological and linguistic issues joined by the contrast between Priestley's empiricist view of chemistry as a branch of natural philosophy and Lavoisier's allegiance to the continental rationalists' views of the aims and methods of theoretical science. $^{3}$

Lavoisier and Priestley shared the epistemological and psychological views of the philosophes. ${ }^{4}$ Within a shared Lockean framework, which reduced the entire content and activity of the mind to sensations and their transformations, Priestley and Lavoisier upheld diverse conceptions of the nature and function of the knowing mind. Priestley adopted Hartley's view of the passivity of the epistemic subject: he viewed thought as the natural product of the mechanical law of association, 
and he reduced discoveries in natural philosophy to the equal ability of all minds to accumulate and inductively order 'facts.' These ideas led him to attack the elitist 'spirit of systems' and the predilection for 'speculation' which accompanied it. ${ }^{5}$ Taking his cue from Condillac, Lavoisier endorsed Priestley's epistemic devaluation of hypotheses which transcend the realm of observable 'facts,' but he did not adopt Priestley's extreme inductivism. Lavoisier accepted Condillac's view of the active knowing mind, and he emphasized the epistemological importance of the theoretical ordering of facts in a manner that was at odds with Priestley's emphasis on the patient accumulation of 'new facts' and the inductive emergence of a 'general theory. ${ }^{\prime}$

The contrasting epistemological allegiences of Lavoisier and Priestley were intertwined with disparate interpretations of the 'method of analysis.' The 'analytic and historical method' deployed by Priestley was shaped by an empiricist methodology of enumerative induction, which contrasted sharply with the rationalist procedure of 'mathematical analysis' underlying Lavoisier's chemistry. ${ }^{7}$ This dimension of Lavoisier's thought bears witness to the influence of Condillac's Logic, which integrated Newton's method of decomposition and Continental views of algebraic analysis into a method of analysis predicated on the doctrine that all reasoning is algebraic in character. ${ }^{8}$ Accordingly, Lavoisier maintained that just as 'mathematicians obtain solutions to a problem by the mere arrangement of data,' so chemists should solve the problems of chemical composition by a 'true mathematical analysis,' in which the unknown composition is identified with a simple recombination of known substances. ${ }^{9}$ This interpretation of the method of analysis was enshrined in Lavoisier's claim that 'all reasoning in scientific matters implicitly contains true equations;' and this view of a 'combinatorial chemistry' led Lavoisier to develop the first genuine chemical equations. ${ }^{10}$

The notion that all scientific reasoning is algebraic in character influenced Lavoisier's doctrine of the composite nature of water, which he formulated and presented in the form of a 'true equation,' or a 'proof,' which approached the logical rigor of mathematical apodexis. Given the Newtonian principle of the conservation of matter and the oxygen theory of combustion, he found it impossible 'to doubt' the 'decomposition and recomposition of water' when 'we see that, in burning together fifteen grams of inflammable air and eighty-five of pure air, we get exactly a hundred grams of water; and when we can, by decomposition, find again the same two principles, in the same proportion. ${ }^{11}$ To doubt this conclusion, Lavoisier claimed, is to doubt the method of analysis, the only route to certainty in science. 
Priestley was of the opposite opinion to his great rival. In place of a rigorous observational versimilitude, which related 'analysis' to the accumulation and inductive ordering of facts, Lavoisier adopted, according to Priestley, the 'synthetic style' of enquiry and presentation, in which facts are rendered subservient to theories. ${ }^{12}$ Besides dismissing the acidic solution that Priestley always obtained in the reaction between oxygen and hydrogen as an impurity-effect due to the presence of nitrogen in the reactants, Lavoisier developed sophisticated experimental procedures and elaborate laboratory apparatus in order to eliminate all impurity-effects from his results and to produce the idealized data necessary for the the formulation of 'true equations in chemistry. ${ }^{13}$ In contrast to Lavoisier, who used a preconceived theory of chemical compositions and reaction mechanisms to distinguish genuine products from impurity-effects in the reaction between hydrogen and oxygen, Priestley structured his phlogistic discourse more in accord with the perceptible properties and interactions of the laboratory substances involved. For Priestley, the passive reception and accumulation of experimental data, obtained by the mind observing nature in a more simple and direct way than that involved in Lavoisier's 'complex' and 'expensive' experiments, indicated that nitric acid was as much a product of the reaction between dephologisticated and inflammable air as was water. ${ }^{14}$ Above all, Priestley maintained that, whatever was the correct interpretation of this experiment, the 'analytic and historical' method of communication required philosophers to provide the public with a faithful record of all their observations, in the order and manner of their occurrence, and not, as in the 'synthetic' mode of discourse, to report the facts 'as if everything had been done to verify a true preconceived theory. ${ }^{\prime} 15$ Whereas Lavoisier interpretated the Enlightenment notion of analysis in terms of a doctrine of experimental 'proof' based on 'demonstrative experiments,' Priestley (and Kirwan) related it to the examination of nature through the use of a 'multitude of experiments,' performed and recorded 'impartially. ${ }^{16}$

\section{II}

The contrasting strains of rationalism and empiricism in the thought of Lavoisier and Priestley surfaced in their respective programmes for the reform of the chemical nomenclature. A useful framework for the analysis of these linguistic sensibilities is provided in Foucault's discussion of the emergence of the Classical episteme from its Renaissance background. ${ }^{17}$ According to this analysis, for philosophers of the Renaissance, language resided in the world as a system of signs enmeshed in the resemblences and similitudes of things. Taking the 
external characteristics of things to signify a hidden power or a relation to other things, the doctrine of signatures maintained that the grammar of natural signs could be deciphered to reveal the syntax of being. The Classical episteme, which provided the underpinnings of the Enlightenment mind, severed this intimate link between words and things. Signatures, which inher in and resemble things, were replaced by signs, which are distinct from the things they represent. The interpretion of the language of nature gave way to the representation of nature in the language of men. The essential epistemological procedure became the classification of phenomena by ordering a system of signs from simple to complex. The method of analysis wedded thought to language. The construction of a precise language was identified with the analytical procedure of creating a systematic science by reducing the data of sensory experience to its representational components.

Condillac summed up this line of thought when he declared that science is nothing but a well-made language.$^{18}$ Lavoisier upheld Condillac's view of the analytical activity of the knowing mind, in which linguistic reform and theoretical development are inextricably linked in the progress of thought from the known to the unknown. ${ }^{19}$ Thus he argued that 'the impossibility of separating the nomenclature of science from the language of science' implied that any change or improvement in the one was inextricably bound up with a change or improvement in the other. ${ }^{20}$ Lavoisier's reform of the chemical nomenclature was intimately related to the logic and development of the oxygen theory, and, as Priestley complained, the former could not be utilized without understanding the latter. ${ }^{21}$

Priestley rejected Lavoisier's new nomenclature because it was based on 'principles ... not ... sufficiently ascertained. ${ }^{22}$ In general, he maintained that contemporary ignorance of the 'primary constituent parts' of bodies meant that Lavoisier's attempt to base his chemical language 'upon a knowledge of the real constituents of natural substances' only ended in confusing 'facts' with mere 'opinions. ${ }^{23}$ In contrast, Priestley designed his 'use of terms' to guarantee the permanence of a scientific language anchored to the epistemic bedrock of 'facts,' rather than the shifting sands of 'hypotheses' and 'conjectures. ${ }^{24}$ In accordance with this regulative linguistic principle, Priestley developed a chemical language to describe the perceptible characteristics, circumstances and transformations of perceptible substances, without any reference to underlying and imperceptible reaction mechanisms and chemical compositions. ${ }^{25}$ Priestley's conception of a permanent scientific language was shaped by the more general, Lockean view that language is a symbolic expression, or description, of independently-existing mental patterns and processes. ${ }^{26}$ Insofar as the Lockean separation of 
thought and language accommodated Priestley's notion that language passively reflects the prelinguistic, mechanical processes of inductive reasoning, it reinforced his conception of a scientific language rooted in the 'facts' of experience and independent of the fluctuating products of the theoretical imagination. In so opposing Lavoisier's reform of the chemical nomenclature, Priestley highlighted characteristic differences between his own empiricist orientation towards observation and experience and Lavoisier's rationalist preference for theorizing and reasoning.

Implicit in Priestley's criticism of Lavoisier's reform of the chemical nomenclature was a rejection of the Classical identification of thought and language with the construction of a conventional system of signs. This strategy did not, however, lead Priestley back to the doctrine of signatures, but to a third, intermediate position. He did not view words as inhering in and resembling things; nor did he view them as constituted by the system of knowledge in which they occurred. For Priestley, signs were neither resident in nature nor constituted by thought. Instead, they were anchored in facts and derived their significance from experience, which grounded thought in nature. In this manner, Priestley's view of the cognitive status and function of language marks an empiricist half-way point between the Renaissance doctrine of natural signatures and the Classical theory of conventional signs.

The claim, advanced by Foucault, that the method of analysis championed by the Enlightenment united classification and mathematization - taxonomia and mathesis - in a single science of order is of limited validity. ${ }^{27}$ While Foucault's interpretation of the Classical episteme seems to capture quite nicely the spirit of Continental rationalism, it fails to recognize the way in which British empiricists such as Priestley related classification to the associations and patterns formed in the observing mind, rather than to the combinatorial constructions of the mathematical intellect. These contrasting views of the method of classification, anchored to different interpretations of the common theme of analysis, highlight important differences between Priestley's view of chemistry as part of the tradition of natural philosophy, characterized by a specific mode of discourse and practice oriented towards the observation and examination of nature, and Lavoisier's program for the construction of a new science of chemistry patterned on mathematical physics. ${ }^{28}$ The extension of this inquiry suggests that the dialectical relation between Lavoisier and Priestley, oxygen and phlogiston, rationalism and empiricism, can all be shown to recapitulate the unity-in-diversity that characterized the Enlightenment as a whole.

JOHN G. McEVOY

University of Cincinnati 


\section{Notes}

1 The account given here of the philosophical mind of the Enlightenment is an interpretative reconstruction of views expressed in Keith M. Baker, Condorcet, From Natural Philosophy to Social Mathematics (Chicago: University Press, 1975), pp. 109-128; J. H. Brumfitt, The French Enlightenment (Cambridge, MA: Schenkman, 1972), pp.12-26; Gerd Buchdahl, The Image of Newton and Locke in the Age of Reason (London and New York: Sheed and Ward, 1961); Ernst Cassirer, The Philosophy of the Enlightenment, trans. F. C. A. Koellin and J. A. Pettegrove (Boston: Beacon Press, 1955), pp. 3-27; Michel Foucault, The Order of Things, An Archaealogy of the Human Sciences (London: Tavistock, 1970), pp. 17-77; Thomas L. Hankins, Science and the Enlightenment (Cambridge: Cambridge University Press, 1985), pp.1-23; Charles Taylor, Hegel (Cambridge: Cambridge Univerity Press), pp. 3-11.

2 Cf. The Enlightenment in National Context, eds., Roy Porter and Miklas Teich (Cambridge: Cambridge University Press, 1981).

3 For a more complete exploration of the relation between the Enlightenment and the Chemical Revolution see John G. McEvoy, 'The Enlightenment and the Chemical Revolution,' Metaphysics and Philosophy of Science in the 17th and 18th Centuries: Essays in Honor of Gerd Buchdahl, ed., Roger Woolhouse (Boston: Nijhoff, forthcoming).

4 Cf. John G. McEvoy and James E. McGuire, 'God and Nature: Priestley's Way of Rational Dissent,' Historical Studies in the Physical Sciences. Sixth Annual Volume, ed. Russell McCormmach (Princeton: Princeton University Press, 1975), pp. 349-357; Henry Guerlac, Antoine-Laurent Lavoisier, Chemist and Revolutionary (New York: Charles Scribner's Sons, 1975), pp. 112-119.

5 Cf. John G. McEvoy, 'Joseph Priestley: 'Aerial Philosopher': Metaphysics and Methodology in Priestly's Chemical Thought, From 1772 to 1781, Part 1,' Ambix, 25 (1978):30-39, (Part 2, Ibid, 153-175; Part 3, Ibid, 153-175; Part 4, Ibid, 26 (1979), 16-38).

6 Cf. Antoine-Laurent Lavoisier, Elements of Chemistry, trans. Robert Kerr (Edinburgh, 1790; reprinted New York: Dover, 1965), pp. xx-xxvii idem, Ouevres, 6 vols. (Paris: Imprimarie Nationale, 1864-1893), 2: 225.

7 Cf. McEvoy, 'Joseph Priestley, Part 1,' pp. 37-38.

8 Cf. William R. Albury, The Logic of Condillac and the Structure of French Chemical and Biological Theory 1780-1801 (Baltimore: The Johns Hopkins University, Unpublished Ph.D. Dissertation, 1972), pp. 31-74 and 110-185; Hankins, Science, pp. 17-23.

9 Lavoisier, Elements p. xviii; Albury, Logic, pp. 64-72 and 128-134.

10 Albury, Logic, pp. 139-150.

11 Antoine-Laurent Lavoisier et al, Méthode de Nomenclature Chimique (Paris: Cuchet, 1787), p. 298.

12 McEvoy, 'Joseph Priestley, Part 1,' pp. 37-38, and Ibid, Part 3, pp. 155-156.

13 Lavoisier, Elements, pp. $94-95$ and 437-441. 
14 Cf. Joseph Priestley, 'Further Experiments Relating to the Decomposition and Recomposition of Dephlogisticated and Inflammable Air,' Philosophical Transactions, 81 (1791), 220-221; idem, The Doctrine of Phlogiston Established and that of the Decomposition of Water Refuted (Northumberland, Pa.: Byrne, 1803), p. 103.

15 Joseph Priestly, The History and Present State of Electricity, with Original Experiments (London: J. Johnson, 1767), p. 574.

16 Richard Kirwan, An Essay on Phlogiston and the Constitution of Acids (London: J. Johnson, 1789), pp. 61 and 307.

17 Cf. Foucault, The Order of Things, pp. 16-73. See also Baker, Condorcet, pp. 109-128; Owen Hannaway, The Chemists and the Word. The Didactic Origins of Chemistry (Baltimore: The Johns Hopkins University Press, 1975), pp. 62-72.

18 Abbé Etienne Bonnot de Condillac, Oeuvres Philosophiques, ed. G. LeRoy, 3 vols. (Paris: Presses Universitaires de France, 1947-51), 2:469.

19 Cf. Maurice Crosland, Historical Studies in the Language of Chemistry (London: Heinemann, 1962), pp. 168-192.

20 Lavoisier, Elements, p. xiv.

21 Priestley, Doctrine of Phlogiston, pp. 104-105.

22 Joseph Priestley, Experiments and Observations on Different Kinds of Air, 3 vols. (London: J. Johnson, 1774-1777), 2: 335.

$23 \mathrm{Ibid}$, p. 30 and Priestley, Doctrine of Phlogiston, p. 105.

24 Cf. McEvoy, 'Joseph Priestley, Part 3,' pp. 154-155.

25 Cf. McEvoy, 'Joseph Priestley.'

26 Cf. McEvoy and McGuire, 'God and Nature,' pp. 354-57.

27 Cf. Foucault, Order of Things, pp. 71-76.

28 For a comparison of these two modes of discourse in eighteenth-century science, cf., respectively, Simon Schaffer, 'Natural Philosophy,' The Ferment of Knowledge. Studies in the Historigraphy of Eighteen-Century Science, eds. G. S. Rousseau and Roy Porter (Cambridge: Cambridge University Press, 1980), pp. 55-92, and Hankins, Science, pp. 1-45. 